\title{
Importance of Human Variation and Scientific Inputs in Designing Furniture
}

\author{
Shivani Chandel, S. L. Malik \\ Department of Anthropology, University of Delhi, Delhi, India
}

Email address:

vs.shivani@gmail.com (S. Chandel)

To cite this article:

Shivani Chandel, S. L. Malik. Importance of Human Variation and Scientific Inputs in Designing Furniture. American Journal of Sports Science. Special Issue: Kinanthropometry. Vol. 4, No. 1-1, 2016, pp. 31-36. doi: 10.11648/j.ajss.s.2016040101.16

\begin{abstract}
The aim of this cross-sectional study was to collect anthropometric data on Kshatriya and Kurmi populations residing in Uttar Pradesh for designing furniture. The sample comprised of 1008 adult Kshatriya (252 males and 252 females) and Kurmi (252 males and 252 females), belonging to the age group of 18-40 yrs. The data was statistically analyzed and the population and sex differences were evaluated by one - way ANOVA. Various percentile values for different body measurements were also calculated. The population and sex differences among the two groups studied revealed significant population and sex differences in various body measurements. Furniture is an important facility that helps in providing a conducive, comfortable and well-designed environment for people. Thus, while designing furniture, human variability in various body dimensions of the user's population must be taken into account with a view to reduce drudgery and at the same time increase efficiency, safety and comfort of the users. Hence an attempt was made to illustrate the relevance of these data in the design of furniture.
\end{abstract}

Keywords: Furniture Designing, Kshatriya, Kurmi, Population Difference, Sex Difference, One-Way ANOVA, Percentiles, Uttar Pradesh

\section{Introduction}

Furniture is one of the vital physical conveniences provided in any surroundings where the people spend most of their time in doing different activities. Therefore, the design of workplace should ensure safety and comfort. The functional utility of the furniture is a result of its physical design in relationship to the physical structure and biomechanics of human body. Human body is intended for movement and time to time changes of posture are necessary for its functioning. Studies have shown that being confined in an awkward posture for specific task in a given situation or using badly designed furniture for a long duration provokes psychological stress and imposes ill effects on human performance [1,2]. Even though the design requirements for seating are different for young and adults, the earlier studies indicate that anthropometric parameters are one of the most important factors in designing comfortable furniture [3]. The body dimensions of the user population are of primary importance in the design of workstations $[4,5,6]$ to accommodate healthy and comfortable posture.

Variation is one of the most important phenomenon occurring in human populations [7, 8, 9] and biological diversity is a characteristic feature of Indian population. From the Himalayan ranges in the north to Kanyakumari in south and from hills of Assam in the east to the deserts of Rajasthan in the west, one comes across considerable variations in body dimensions of people. With the emergence of newly industrialized countries, ie, developing and under developed nations, the need to design different man-machine environments to fit all populations is being very strongly felt now. Designs that once suited the western populations have been followed in India despite of the fact that there is considerable difference between the anthropometric data of Indians and westerners [10]. As the population and sex differences in anthropometric data in various regions of India are not slight but considerable, it becomes important to take these into account while designing equipment and physical facilities. While it is impossible to design systems to suit all the people of different body types and sizes, considering hundreds of measurements, it is prudent to deal at least with the important key body dimensions.

The anthropometric data provide important information in the design of work spaces, equipment, furniture, and clothing $[5,11,12,13,14]$. Anthropometric data is helpful in finding 
human variation among user population to achieve effective design for high performance and productivity [15]. Appropriate use of anthropometry in design may improve the well-being, health, comfort, and safety of a product's users $[5,16,17]$. There is an urgent need to collect anthropometric data for Indian population in order to introduce changes in equipment design and use. The present study is thus an attempt to find out population and sex differences in the relevant anthropometric dimensions that could be used in the design of furniture of two population groups of Kshatriya and Kurmi of Uttar Pradesh. This will provide designers with an updated source of anthropometric data for the design of products and workplaces that are safe, efficient and comfortable. The comfort, physical health, well-being, and performance of people will be increased by designing equipments, goods, furniture, and other devices according to the requirements of the human body.

\section{Method}

A cross sectional sample of 1008 adult Kshatriya (252 males and 252 females) and Kurmi (252 males and 252 females) belonging to the age group of 18-40 yrs was collected using multi-stage sampling. The data for the Kshatriya population was collected from the Akbarpur subdivision of Ramabai Nagar, while that of Kurmi population was collected from the Fatehpur subdivision of Fatehpur district of Uttar Pradesh. Uttar Pradesh is the most populous state of our country with 71 districts (Census of India, 2011) where the major occupation is farming. Kshatriya or Kashtriya, meaning warrior, is one of the four castes (social orders) in Hinduism. It traditionally constituted the military and ruling elite of the Vedic-Hindu social system outlined by the Vedas and the Laws of Manu. In modern times, the Kshatriya caste includes a broad class of caste groups, differing considerably in status and function but united by their claims to ruler-ship, the pursuit of war, or the possession of land. Kshatriya marriages show caste endogamy and subcaste exogamy.

Kurmi is a large peasant community of farmers widely distributed in the states of Uttar Pradesh, Bihar, Madhya Pradesh, Punjab and Assam. They have eleven main divisions that follow caste endogamy and subcaste endogamy. Kurmi are often identified on the basis of the region they hail. For example, those from Uttar Pradesh are known as Purabia Kurmi, those from Bihar, Bihari Kurmi, and those from Madhya Pradesh as Manwa Kurmi and so on. They are listed among the Other Backward Class (OBC) and receive benefits from the government accordingly.

In accordance with the aims and objectives of the study following body measurements were taken: Height vertex, Sitting height vertex, Body Weight, Trunk Height, Biacromial breadth, Bideltoid breadth, Maximum hip width, Popliteal height, Knee height, Buttock knee length, Buttock popliteal length, Lumbar height, Elbow height and Elbow to elbow breadth in accordance with internationally accepted standards [18, 19]. In statistical analysis, mean, standard error and coefficient of variation for these measurements were computed using statistical analysis software (SPSS 16 and MS Excel). Population and sex differences in all these variables were assessed using analysis of variance (ANOVA). Percentile values of $1^{\text {st }}, 3^{\text {rd }}, 5^{\text {th }}, 25^{\text {th }}, 50^{\text {th }}, 75^{\text {th }}, 95^{\text {th }}, 97^{\text {th }}$ and $99^{\text {th }}$ for different body dimensions were also calculated.

\section{Result}

Table 1. Percentile distribution of Body dimensions among Kshatriya Males.

\begin{tabular}{|c|c|c|c|c|c|c|c|c|c|c|c|}
\hline \multirow{2}{*}{ Measurements } & \multirow{2}{*}{ Mean } & \multirow{2}{*}{ SD } & \multicolumn{9}{|c|}{ Percentiles } \\
\hline & & & $1^{\text {st }}$ & $3^{\text {rd }}$ & $5^{\text {th }}$ & $25^{\text {th }}$ & $50^{\text {th }}$ & $75^{\text {th }}$ & $95^{\text {th }}$ & $97^{\text {th }}$ & $99^{\text {th }}$ \\
\hline Height Vertex, cm & 166.96 & 5.02 & 158 & 159.1 & 160.6 & 162.7 & 166.9 & 170 & 172.2 & 173.5 & 174.7 \\
\hline Body Weight, kg & 54.08 & 6.26 & 46.0 & 46.5 & 47.5 & 50.0 & 55.0 & 59.5 & 65.0 & 64.0 & 65.5 \\
\hline Sitting Height Vertex, cm & 87.36 & 3.04 & 82.1 & 82.3 & 82.5 & 85.1 & 87.3 & 89.2 & 92.2 & 93.4 & 94.2 \\
\hline Trunk Height, cm & 64.87 & 2.82 & 60.2 & 60.4 & 60.6 & 62.3 & 65.1 & 66.9 & 70.4 & 70.6 & 70.7 \\
\hline Popliteal Height, cm & 43.27 & 2.08 & 40.2 & 40.4 & 40.5 & 41.1 & 43.2 & 45.0 & 47.0 & 47.1 & 47.2 \\
\hline Knee Height, cm & 52.76 & 1.8 & 50 & 50.1 & 50.2 & 51.4 & 52.3 & 54.1 & 56.1 & 56.5 & 57.2 \\
\hline Buttock Knee Length, cm & 54.04 & 2.08 & 50.5 & 50.9 & 51.1 & 52.4 & 54.0 & 55.4 & 57.6 & 58.2 & 58.3 \\
\hline Buttock Popliteal Length, cm & 43.48 & 2.13 & 40.1 & 40.4 & 40.5 & 41.6 & 43.5 & 44.7 & 47.9 & 48.1 & 48.3 \\
\hline Lumbar Height, cm & 23.55 & 1.53 & 21.0 & 21.0 & 21.1 & 22.1 & 23.0 & 24.6 & 25.7 & 26.4 & 27.2 \\
\hline Elbow Height, cm & 22.62 & 1.33 & 20.0 & 20.1 & 20.4 & 21.6 & 22.8 & 24.0 & 24.4 & 24.5 & 24.5 \\
\hline Maximum Hip Width, cm & 33.31 & 1.77 & 31.0 & 31.0 & 31.1 & 31.6 & 33.0 & 34.7 & 36.3 & 38.5 & 39.5 \\
\hline Elbow to Elbow Breadth, cm & 39.5 . & 2.56 & 35.0 & 35.1 & 35.2 & 37.8 & 39.1 & 42.2 & 43.2 & 43.3 & 43.4 \\
\hline Biacromial breadth, cm & 38.07 & 2.22 & 34.3 & 34.5 & 34.9 & 36.2 & 38.1 & 40.0 & 42.2 & 43.2 & 43.4 \\
\hline Bideltoid breadth, $\mathrm{cm}$ & 40.89 & 2.38 & 35.2 & 35.4 & 37.0 & 39.3 & 41.0 & 42.4 & 45.0 & 46.0 & 46.5 \\
\hline
\end{tabular}

Table 2. Percentile distribution of Body dimensions among Kshatriya females.

\begin{tabular}{|c|c|c|c|c|c|c|c|c|c|c|c|}
\hline \multirow{2}{*}{ Measurements } & \multirow{2}{*}{ Mean } & \multirow{2}{*}{ SD } & \multicolumn{9}{|c|}{ Percentiles } \\
\hline & & & $1^{\text {st }}$ & $3^{\text {rd }}$ & $5^{\text {th }}$ & $25^{\text {th }}$ & $50^{\text {th }}$ & $75^{\text {th }}$ & $95^{\text {th }}$ & $97^{\text {th }}$ & $99^{\text {th }}$ \\
\hline Height Vertex, cm & 152.29 & 4.13 & 146 & 146.5 & 147.4 & 149.5 & 152 & 155.1 & 157.3 & 158.3 & 159.5 \\
\hline Body Weight, kg & 48.17 & 4.94 & 36.3 & 38.0 & 38.5 & 43.0 & 48.0 & 52.0 & 56.2 & 56.7 & 58.5 \\
\hline Sitting Height Vertex, cm & 78.43 & 3.45 & 73.1 & 73.4 & 74.1 & 77.0 & 78.5 & 82.0 & 85.5 & 85.7 & 86.2 \\
\hline Trunk Height, cm & 58.72 & 2.89 & 53.3 & 53.6 & 54.0 & 56.7 & 58.4 & 61.2 & 63.4 & 63.6 & 63.7 \\
\hline
\end{tabular}




\begin{tabular}{|c|c|c|c|c|c|c|c|c|c|c|c|}
\hline \multirow{2}{*}{ Measurements } & \multirow{2}{*}{ Mean } & \multirow{2}{*}{ SD } & \multicolumn{9}{|c|}{ Percentiles } \\
\hline & & & $1^{\text {st }}$ & $3^{\text {rd }}$ & $5^{\text {th }}$ & $25^{\text {th }}$ & $50^{\text {th }}$ & $75^{\text {th }}$ & $95^{\text {th }}$ & $97^{\text {th }}$ & $99^{\text {th }}$ \\
\hline Popliteal Height, cm & 40.84 & 2.02 & 37.2 & 37.4 & 37.6 & 39.3 & 40.4 & 42.4 & 44.3 & 44.6 & 44.7 \\
\hline Knee Height, cm & 50.83 & 2.4 & 46.2 & 46.5 & 46.8 & 48.9 & 50 & 52.2 & 53.2 & 54.3 & 54.5 \\
\hline Buttock Knee Length, cm & 51.28 & 1.73 & 48 & 48.1 & 48.2 & 50.3 & 51.3 & 52.4 & 53.5 & 54.4 & 54.7 \\
\hline Buttock Popliteal Length, cm & 41.38 & 1.7 & 37.1 & 37.9 & 38.2 & 39.4 & 41.4 & 42.3 & 44.3 & 44.6 & 46.1 \\
\hline Lumbar Height, cm & 21.71 & 1.42 & 20.0 & 20.0 & 20.1 & 20.8 & 22.0 & 23.4 & 24.5 & 25.4 & 26 \\
\hline Elbow Height, cm & 18.52 & 1.06 & 18.1 & 18.2 & 18.2 & 18.7 & 20 & 21.2 & 22 & 22.3 & 22.5 \\
\hline Maximum Hip Width, cm & 32.81 & 1.89 & 29.1 & 29.9 & 30.1 & 30.6 & 31.5 & 33.2 & 35.0 & 360 & 37.0 \\
\hline Elbow to Elbow Breadth, $\mathrm{cm}$ & 35.59 & 2.38 & 32.0 & 32.1 & 32.2 & 33 & 36.1 & 37.4 & 39.2 & 39.3 & 39.9 \\
\hline Biacromial breadth, $\mathrm{cm}$ & 33.98 & 1.77 & 30.2 & 30.4 & 30.6 & 32.3 & 34.3 & 35.4 & 36.2 & 36.3 & 37.2 \\
\hline Bideltoid breadth, cm & 37.91 & 2.25 & 33.1 & 33.4 & 34.5 & 36.5 & 37.3 & 39.2 & 40.1 & 41 & 41.5 \\
\hline
\end{tabular}

Table 3. Percentile distribution of Body dimensions among Kurmi Males.

\begin{tabular}{|c|c|c|c|c|c|c|c|c|c|c|c|}
\hline \multirow{2}{*}{ Measurements } & \multirow{2}{*}{ Mean } & \multirow{2}{*}{ SD } & \multicolumn{9}{|c|}{ Percentiles } \\
\hline & & & $1^{\text {st }}$ & $3^{\text {rd }}$ & $5^{\text {th }}$ & $25^{\text {th }}$ & $50^{\text {th }}$ & $7^{\text {th }}$ & $95^{\text {th }}$ & $97^{\text {th }}$ & $99^{\text {th }}$ \\
\hline Height Vertex, $\mathrm{cm}$ & 166.75 & 4.85 & 157 & 158.8 & 161.2 & 164.4 & 166.4 & 169.2 & 172 & 173.1 & 174.5 \\
\hline Body Weight, kg & 55.76 & 4.54 & 44 & 44.5 & 47.8 & 53 & 55 & 58.5 & 63.5 & 63.5 & 65 \\
\hline Sitting Height Vertex, cm & 85.61 & 3.36 & 79.9 & 80.2 & 81.3 & 83.8 & 86.4 & 88.2 & 89.5 & 90.7 & 91 \\
\hline Trunk Height, cm & 64.93 & 2.99 & 58.3 & 58.5 & 60.3 & 62.2 & 65.1 & 67.7 & 68.8 & 69 & 69.3 \\
\hline Popliteal Height, cm & 43.23 & 2.37 & 40.1 & 40.1 & 40.2 & 41.3 & 43 & 45.2 & 47.6 & 47.9 & 48 \\
\hline Knee Height, cm & 52.31 & 3.05 & 47.2 & 47.4 & 47.5 & 50.2 & 52.2 & 53.4 & 58.2 & 58.5 & 58.7 \\
\hline Buttock Knee Length, cm & 55.08 & 2.67 & 49.1 & 49.4 & 50.2 & 53.3 & 55 & 58.2 & 58.9 & 59 & 59.1 \\
\hline Buttock Popliteal Length, cm & 44.7 & 2.76 & 40 & 40.2 & 41.2 & 42.4 & 45 & 46.9 & 48.4 & 48.5 & 48.6 \\
\hline Lumbar Height, cm & 22.71 & 1.59 & 20 & 20.1 & 20.2 & 21.4 & 22.8 & 23.8 & 25.2 & 25.3 & 25.4 \\
\hline Elbow Height, $\mathrm{cm}$ & 22.26 & 1.48 & 20 & 20.1 & 20.2 & 20.8 & 22.1 & 23.7 & 24.5 & 24.6 & 24.8 \\
\hline Maximum Hip Width, cm & 35 & 2.09 & 31.3 & 31.6 & 32 & 33.6 & 34.5 & 36.4 & 38 & 39.1 & 39.3 \\
\hline Elbow to Elbow Breadth, $\mathrm{cm}$ & 41.61 & 2.84 & 37 & 37.2 & 37.3 & 39 & 41.7 & 43.4 & 46.6 & 46.8 & 47 \\
\hline Biacromial breadth, $\mathrm{cm}$ & 40.85 & 2.17 & 37.1 & 37.3 & 37.4 & 39.2 & 40.7 & 42.4 & 45.2 & 45.4 & 45.6 \\
\hline Bideltoid breadth, $\mathrm{cm}$ & 43.78 & 2.39 & 39.3 & 39.6 & 40 & 41.6 & 43.9 & 44.9 & 47.4 & 47.5 & 47.7 \\
\hline
\end{tabular}

Table 4. Percentile distribution of Body dimensions among Kurmi females.

\begin{tabular}{|c|c|c|c|c|c|c|c|c|c|c|c|}
\hline \multirow{2}{*}{ Measurements } & \multirow{2}{*}{ Mean } & \multirow{2}{*}{ SD } & \multicolumn{9}{|c|}{ Percentiles } \\
\hline & & & $1^{\text {st }}$ & $3^{\text {rd }}$ & $5^{\text {th }}$ & $25^{\text {th }}$ & $50^{\text {th }}$ & $75^{\text {th }}$ & $95^{\text {th }}$ & $97^{\text {th }}$ & $99^{\text {th }}$ \\
\hline Height Vertex, $\mathrm{cm}$ & 155.79 & 3.34 & 150 & 151 & 152.5 & 153.8 & 155.8 & 158.2 & 161.4 & 162.4 & 163.3 \\
\hline Body Weight, kg & 47.92 & 4.58 & 39 & 40.3 & 40.8 & 45 & 47.3 & 51 & 56 & 56.5 & 57 \\
\hline Sitting Height Vertex, cm & 78.42 & 3.4 & 71.2 & 73.5 & 75 & 77.4 & 78.9 & 80.1 & 81.6 & 84 & 85.3 \\
\hline Trunk Height, cm & 58.44 & 2.5 & 54.4 & 54.7 & 55 & 57.1 & 58.1 & 59.8 & 63.3 & 64.3 & 65.6 \\
\hline Popliteal Height, cm & 41.51 & 2.24 & 38.2 & 38.5 & 39 & 39.7 & 41.1 & 43 & 45.6 & 46 & 46.5 \\
\hline Knee Height, cm & 50.6 & 2.39 & 44.9 & 45 & 45.2 & 48 & 50.4 & 51.5 & 54.8 & 55 & 55.2 \\
\hline Buttock Knee Length, cm & 52.5 & 2.48 & 47 & 47.2 & 48.4 & 50.3 & 52.4 & 54.4 & 55.9 & 56.3 & 56.7 \\
\hline Buttock Popliteal Length, cm & 43.6 & 2.56 & 38.3 & 38.4 & 39.5 & 40.4 & 43.5 & 45.3 & 46.4 & 47 & 47.2 \\
\hline Lumbar Height, cm & 21.55 & 1.55 & 19.1 & 19.2 & 19.3 & 20.3 & 21.3 & 22.3 & 24.4 & 24.5 & 24.6 \\
\hline Elbow Height, cm & 21.69 & 1.5 & 19 & 19.1 & 19.2 & 19.3 & 20.9 & 22 & 23.6 & 23.7 & 23.8 \\
\hline Maximum Hip Width, cm & 32.48 & 1.91 & 29.1 & 29.3 & 29.9 & 30.7 & 32.3 & 34.3 & 35.4 & 35.6 & 35.8 \\
\hline Elbow to Elbow Breadth, cm & 37.58 & 2.57 & 32.1 & 32.4 & 33 & 36 & 38 & 39.3 & 42 & 42.2 & 42.3 \\
\hline Biacromial breadth, $\mathrm{cm}$ & 34.13 & 1.82 & 31 & 31.1 & 31.2 & 32.6 & 34.1 & 35.4 & 37.1 & 37.2 & 37.4 \\
\hline Bideltoid breadth, $\mathrm{cm}$ & 38.87 & 2.18 & 33.3 & 33.4 & 33.6 & 36 & 39 & 40.3 & 42.2 & 42.3 & 42.5 \\
\hline
\end{tabular}

Table 5. Body dimensions, by population (*Significant at $5 \%$ probability **One Way ANOVA).

\begin{tabular}{lllllll}
\hline \multirow{2}{*}{ Body dimensions } & \multicolumn{5}{l}{ Males } & \multicolumn{5}{l}{ Females } \\
\cline { 2 - 7 } & F $^{* *}$ value & d. f & Sig. & F value & d. f & Sig. \\
\hline Trunk Height, cm & 0.066 & $1 / 502$ & 0.797 & 1.338 & $1 / 502$ & 0.248 \\
Popliteal Height, cm & 0.05 & $1 / 502$ & 0.823 & $12.489^{*}$ & $1 / 502$ & 0.000 \\
Knee Height, cm & $4.141^{*}$ & $1 / 502$ & 0.042 & 1.22 & $1 / 502$ & 0.270 \\
Buttock Knee Length, cm & $23.980^{*}$ & $1 / 502$ & 0.000 & $41.200^{*}$ & $1 / 502$ & 0.000 \\
Buttock Popliteal Length, cm & $31.065^{*}$ & $1 / 502$ & 0.000 & $131.489^{*}$ & $1 / 502$ & 0.000 \\
Biacromial Breadth, cm & $203.00^{*}$ & $1 / 502$ & 0.000 & 0.907 & $1 / 502$ & 0.341 \\
Lumbar Height, cm & $36.566^{*}$ & $1 / 502$ & 0.000 & 1.362 & $1 / 502$ & 0.244 \\
Elbow Height, cm & $8.440^{*}$ & $1 / 502$ & 0.004 & $747.917^{*}$ & $1 / 502$ & 0.000 \\
Maximum Hip Width, cm & $96.073^{*}$ & $1 / 502$ & 0.000 & 3.649 & $1 / 502$ & 0.057 \\
Elbow to Elbow Breadth, cm & $76.363^{*}$ & $1 / 502$ & 0.000 & $81.559^{*}$ & $1 / 502$ & 0.000 \\
Bideltoid Breadth, cm & $185.513^{*}$ & $1 / 502$ & 0.000 & $23.323^{*}$ & $1 / 502$ & 0.000 \\
\hline
\end{tabular}


Table 6. Body dimensions, by sex (*Significant at 5\% probability level **One Way ANOVA).

\begin{tabular}{|c|c|c|c|c|c|c|}
\hline \multirow{2}{*}{ Body dimensions } & \multicolumn{3}{|l|}{ Kshatriya } & \multicolumn{3}{|l|}{ Kurmi } \\
\hline & $F^{* *}$ value & d. $f$ & Sig. & F value & d. $f$ & Sig. \\
\hline Trunk Height, $\mathrm{cm}$ & $585.412 *$ & $1 / 502$ & 0.000 & $698.864^{*}$ & $1 / 502$ & 0.000 \\
\hline Popliteal Height, cm & $178.073 *$ & $1 / 502$ & 0.000 & $70.405^{*}$ & $1 / 502$ & 0.000 \\
\hline Knee Height, cm & $104.154 *$ & $1 / 502$ & 0.000 & $49.266^{*}$ & $1 / 502$ & 0.000 \\
\hline Buttock Knee Length, cm & $261.452 *$ & $1 / 502$ & 0.000 & $126.169^{*}$ & $1 / 502$ & 0.000 \\
\hline Buttock Popliteal Length, cm & $149.824 *$ & $1 / 502$ & 0.000 & $21.674^{*}$ & $1 / 502$ & 0.000 \\
\hline Bicromial breadth, cm & $522.98 *$ & $1 / 502$ & 0.000 & $1418.22 *$ & $1 / 502$ & 0.000 \\
\hline Elbow Height, cm & $1462.484^{*}$ & $1 / 502$ & 0.000 & $18.351 *$ & $1 / 502$ & 0.000 \\
\hline Maximum Hip Width, cm & $9.722 *$ & $1 / 502$ & 0.002 & $199.789^{*}$ & $1 / 502$ & 0.000 \\
\hline Elbow to Elbow Breadth, $\mathrm{cm}$ & $315.611 *$ & $1 / 502$ & 0.000 & $278.565^{*}$ & $1 / 502$ & 0.000 \\
\hline Bideltoid Breadth, cm & $207.989 *$ & $1 / 502$ & 0.000 & $581.293 *$ & $1 / 502$ & 0.000 \\
\hline
\end{tabular}

\section{Discussion}

As human beings perform most of their work in the sitting position, it becomes important to design comfortable and good seating systems. Table 1, 2, 3 and 4 presents Mean, SD and $1^{\text {st }}, 3^{\text {rd }}, 5^{\text {th }}, 25^{\text {th }}, 50^{\text {th }}, 75^{\text {th }}, 95^{\text {th }}, 97^{\text {th }}$ and $99^{\text {th }}$ percentile values of all 14 body dimensions generally required for furniture to be designed for males and females. Ten important measurements are generally required for a chair to be designed viz. Sitting Height, Popliteal Height, Buttock Popliteal Length, Maximum Hip Width, Trunk Height, Lumbar Height, Biacromial Breadth, Bideltoid Breadth, Elbow Height and Elbow to Elbow breadth [7].

The popliteal height forms the basis of the chair height [7]. To achieve an optimum seat height, the fifth percentile should be used by designers $[4,16]$. Like in this case, for Kshatriya males $40.5 \mathrm{~cm}$ whereas $37.6 \mathrm{~cm}$ popliteal height should be used for Kshatriya females. Likewise a $40.2 \mathrm{~cm}$ height is usable in the case of Kurmi males and $39 \mathrm{~cm}$ in the case of Kurmi females.

The relevant body measurement for designing seat/ chair width is maximum hip width in sitting position [7, 20, 21]. As it is clearance measurement the value of $95^{\text {th }}$ percentile should be taken into account $[4,16,22]$. A seat width of 36.3 $\mathrm{cm}$ for Kshatriya males and $35 \mathrm{~cm}$ for Kshatriya females should be used while designing chair. Likewise, $38 \mathrm{~cm}$ is usable in the case of Kurmi males and $35.4 \mathrm{~cm}$ in the case of Kurmi females while designing seat width.

Buttock-popliteal length (sitting) is helpful for the determination of depth of the seat $[10,23]$. The depth of the seat should be designed based on the $5^{\text {th }}$ percentile value of buttock popliteal length $[4,16,22]$. In the population groups discussed here, for Kshatriya males 40.5 and for females $38.2 \mathrm{~cm}$ should be used while designing seat depth. Whereas, among Kurmis $41.2 \mathrm{~cm}$ in the case of males and $39.5 \mathrm{~cm}$ in the case of females should be used while considering seat depth.

Various types of backrests can be designed as per the need of the user. The height of the backrest is designed considering measurement on various parts of the trunk, viz. biacromial, and lumbar and trunk height, in different types of backrest depending upon their ultimate application [7]. The width should be designed on the basis of either biacromial breadth or bideltoid breadth and because it is a clearance measurement, dimensions of the $95^{\text {th }}$ percentile person should be used. Also, the backrest must be capable of supporting the entire width of the back as well as should provide support for the lower back, i. e., lumber vertebrae [21]. Chakrabarti and Das [10]considered lumber height from seat for determining the lowest point height of the back support. To achieve an optimum design, seat backrest height should be kept at 60 $80 \%$ of shoulder height or be approximately $100 \mathrm{~mm}$ below shoulder height, so arm movements are not restricted [16]. In any case, the level of the top of the backrest is determined by the fifth percentile.

According to researchers, Knee Height is needed to design below-desk height $[4,21,24]$. To achieve an optimum design, underneath desk height should be between $20 \mathrm{~mm}$ to $50 \mathrm{~mm}$ higher than knee height which is determined by the 95th percentile [25]. If below desk height is designed at this level, it does not only allow free thighs and lower legs movement, but it allows for knee crossing as well.

Buttock-knee length (sitting) may be helpful for the assessment of horizontal space below the desk for accommodating the knees of the users [24].

The chairs where arm rest is required and they do not obstruct the productivity of the work should be endowed with them. The best position of the arm rest is elbow height but to provide armrest to each person at their respective elbow height makes it necessary for them to be adjustable [7, 23]. In the absence of that, when only a single stationary arm rest has to be provided, then designing according to the value of the $50^{\text {th }}$ percentile man seems to be rational. Elbow height is needed to design desk (table) top height and/or the arm rest $[3,7,20,23]$. To design an optimum desk top, desk top height should be $30-50 \mathrm{~mm}$ higher than elbow height [16] or be adjusted to elbow height [25]. In any case, the desk (table) top height is determined by the fifth percentile.

Seat height (i. e. popliteal height), seat depth (i. e. buttock popliteal length), desk clearance (knee height) are the key measurements considered in bench design based on ergonomic principles $[25,26]$. So, data of these measurements obtained from the present investigation can also be used to design benches. However, the upper surface height of the seat (bench) corresponds to the popliteal height of the population is under consideration [21]. Other investigators $[10,20]$ also hold the same opinion. To design 
the length of the seat (bench), the sitting bi-deltoid breadth should be considered, in case of multiple users' seat. The data of the same collected from the present investigation will serve the purpose. Kroemer and Grandjean [22] express that if we consider the measurement 'ground-to-upper surface of knee' and make certain additions to allow for heels and for a minimum amount of movement, we will get the space for free knee room. So, it can be said that the dimension of sitting knee height of the present investigation will be helpful for the determination of free knee room under the desk. The sitting lumber (5th) height collected from the present investigation may be used for determining the lower edge height of the backrest from the bench surface. This is also suggested by Chakrabarti and Das [10].

To conclude, the population and sex differences among the two groups studied revealed significant differences in various body measurements applicable in designing furniture. Kurmi males have significantly greater Buttock Knee Length, Buttock Popliteal Length, Maximum Hip Width, Elbow to Elbow Breadth and Bideltoid Breadth whereas Kshatriya males have significantly greater Lumbar Height. Nonsignificant differences are observed in Trunk Height, Popliteal Height, Knee Height and Elbow Height. Kurmi females are significantly greater in Popliteal Height, Buttock Knee Length, Buttock Popliteal Length, Elbow Height, Elbow to Elbow Breadth and Bideltoid Breadth. Nonsignificant differences are observed in Trunk Height, Maximum Hip Width, Knee Height and Lumbar Height. Distinct sex differences are observed in all the above mentioned measurements among Kshatriya and Kurmi with males significantly higher in all the body dimensions than their female counterparts.

With the development of technology the importance of designing of products using scientific knowledge has increased. The increasing necessity of involving human variability in designing of products has resulted in an increased application of anthropometry. Since anthropologists have an expertise in studying human variation in body size and shape through anthropometry, they are well equipped for accomplishing such a task. However, there still remain many lacunae and limitations in design of products as information of the human requirements and data on human body dimensions still fall short of what would be desirable. There exists a need to generate anthropometric data for Indian population in order to let the system designers design and develop different types of products using human variation. The anthropometric data presented in the form of percentiles in this section is usable in designing furniture. As everyday new researches are coming up to help to improve designing, it can therefore be expected that designing of furniture will continue to improve.

\section{Acknowledgement}

The authors would like to thank all participants in this study and are grateful for the financial assistance rendered by the Indian Council of Social Science Research (ICSSR).

\section{References}

[1] Mittal, M., Malik, S. L., Workposture: ergonomic implications and human health. Indian Anthropologist, 16: 57-59, 1986.

[2] Das, A., Chakrabarti, D., Role of free postural adoption on performance and informal workplace design. Proceedings of National Conference on Humanizing Work and Work environment, National Institute of Industrial Engineering, April, Mumbai, 2004.

[3] Straker, L., Pollock, C., Burgess-Limerick, R., Excerpts from CybErg 2005 discussion on preliminary guidelines for wise use of computers by children. Int J Industrial Ergon. 36 (12): 1089-1095, 2006.

[4] Helander, M. G., Czaja, S. J., Drury, C. G., Cary, J. M., An ergonomic evaluation of office chairs. Office: Technology and People, 1987, 3: 247-262.

[5] Malik, S. L., Anthropometry and designing: problems, prospects and research strategies. J. Hum. Ecol. 6(1): 33-42, 1995.

[6] Harris, C., Straker, L., Pollock, C. and Trinidad, S., Musculoskeletal outcomes in children using information technology the need for a specific etiological model. Int. J Industrial Ergon, 35: 131-138, 2005.

[7] Malik, S. L. and Bhattacharya, D. K.: Aspects of Human Ecology: A Dynamic Inter-Relationship between Man and Environment. Northern Book Centre, Delhi, 1986.

[8] Ruff, C., Variation in body size and shape. Annu. Rev. Anthropol., 31: 211-232, 2002.

[9] Pandey, A. K., Anthropometry of female Onges of Little Andaman. Anthropologist., 8 (2): 99-102, 2006.

[10] Chakrabarti, D., Das, A., Design development of New Seatdesk Unit suitable for Indian school children. Proceedings of National conference on Humanizing Work and Work Environment, National Institute of Industrial Engineering, April, Mumbai, 2004.

[11] Jeong, B. Y., Park, K. S., Sex differences in anthropometry for school furniture design. Ergonomics. 33: 1511-1521, 1990.

[12] Kayis, B., and Ozok, A. F., The anthropometry of Turkish army men. Appl. Ergon. 22: 49-54, 1991.

[13] Bridger, R. S., Introduction to Ergonomics, McGraw-Hill, New York, 1995.

[14] Tayyari, F., Smith, J. L., Occupational Ergonomics: Principles and applications. Kluwer Acad. Publ. London, 2000.

[15] Hanson, L., Sperling, L., Gard, G., Ipsen, S., Vergara, C. O., Swedish anthropometrics for product and workplace design. Appl. Ergonomics. 40: 797-806, 2009.

[16] Klamklay, J., Sungkhapong, A., Yodpijit, N., Patterson, P. E.: Anthropometry of the southern Thai population. Int. J. Industr. Ergon. 38: 111-118 (2008).

[17] Pheasant, S. T.: Bodyspace: Anthropometry, Ergonomics and the Design of Work, second ed. s. Taylor and Francis Ltd, London, 1998. 
[18] Barroso, M. P., Arezes, P. M., Costa, L. G., Miguel, A. S., Anthropometric study of Portuguese workers, Int. J. Indust Ergon. 35 (4): 401-410, 2005.

[19] Martin, R., Saller., Lehrbuch der Anthropologie. Gustav Fischer Verlag, Stuttgart, 1957.

[20] Tanner, J. M., Hiernaux, J., Jarnan, S., Growth and Physique Studies, pp. 315-340. In: Human Biology: A Guide to Field Methods. IBP Hand book no. 9. J. S Weiner and J. A. Lourie (Eds.). Blackwell Scientific Publication, Oxford, 1969.

[21] Molenbroek, J. F. M., Kroon-Ramaekers, Y. M. T., Snijders, C. J., Revision of the design of a standard for the dimensions of school furniture. Ergonomics, 46: 681-694, 2003.

[22] Sane, S. M., Karandikar, V., Savale, P.: Ergonomic Product Design: Classroom Bench. Proceedings of National
Conference on Humanizing Work and Work Environment, National Institute of Industrial Engineering, April, Mumbai (2004).

[23] Kroemer, K. H. E., Grandjean, E., Fitting the Task to the Human: A Text Book of Occupational Ergonomics. Taylor and Francis, London, 2001.

[24] Malik, S. L., Jurgens, H. W., Helbig, K., Designing a chair: a scientific perspective. Indian Anthropologist. 14: 41-61, 1986.

[25] Khaspuri, G. C., Sau, S. K., Dhara, P. C., Anthropometric consideration for designing class room furniture in rural schools. J. Hum Ecol., 22 (3): 235-244, 2007.

[26] Parcells, C., Stommel, M., Hubbard, R. P., Mismatch of classroom furniture and student body dimensions. $J$ Adolescent Health. 24, 265-273, 1999. 